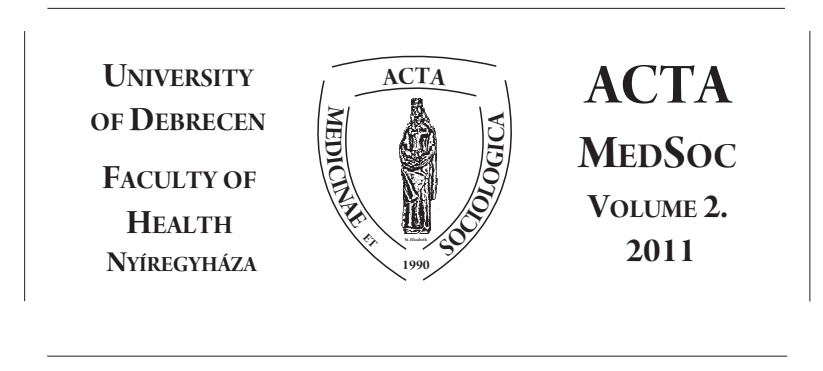

\title{
Equal opportunities and regional inequalities
}

\author{
Ildikó Balatoni \\ University of Debrecen, Health and Science Center, \\ Office of Strategic Management
}

\begin{abstract}
Any measure taken to ensure equal opportunities only reaches its objective if it is implemented and becomes practice rather than remaining in the letters of regulations. It is essential that government and civil organisations pay special attention to the dissemination of approaches to equal opportunity. In this paper I aim to examine expectations set by legislators towards higher education institutions in Hungary and whether ensuring equal opportunities at a higher education institution could contribute to reducing regional inequalities. I will narrow down the scope of issues based on the equal opportunity priorities defined in application structures funded by the European Union, examining the practice of the University of Debrecen.
\end{abstract}

Keywords: region, equal opportunities, higher education, applications for funding DOI: $10.19055 / \mathrm{ams} .2011 .2 / 2 / 8$

\section{Introduction}

There probably has never been such a period in Hungarian history like the current one when ensuring equal opportunities has been in the forefront to this extent. This tendency is becoming more and more perceptible in every social and economic organisation, as the mechanisms intended to guarantee equal treatment receive more attention both domestically and at a European level as well. Never have so many regulations and specific actions been made regarding these issues as currently. It is 
questionable however, how countless policies, official statements and internal regulations actually get implemented. Scepticism can be regarded as a natural reaction from all affected social and economic parties to all the latest legal framework, that in all fairness, influences their internal operation and are also often difficult to interpret.

In this paper I aim to examine expectations set by legislators towards higher education institutions in Hungary and how these are met by the abovementioned institutions. I will narrow down the scope of issues based on the equal opportunity priorities defined in application structures financed by European Union funds, examining the practice of the University of Debrecen in particular. As the regional role of universities could be significant from both an employment and a human resource development aspect, I find it necessary to reveal problems in Hungary and introduce relevant data of the Northern Great Plain region.

\section{Domestic conditions and data of the Northern Great Plain}

It is a nationwide phenomenon that beside what is traditionally defined as poverty, which is primarily characterised by low levels of education, agricultural or vocational jobs, a "new type of poverty" also appeared, which is primarily characterised by unemployment, and being pushed out of the labour-market (Spéder 1996, Spéder 2002). Child poverty is a very complex phenomenon which is caused by and is a consequence of parental unemployment, regional and institutional segregation, unequal access to human services and information, legal offences including rights of children, human or social rights (Bass and assoc. 2008). According to Ferge (2008), the most severe current problem in Hungary is the unlimited increase of inequalities in all areas. Bass and associates (2008) came to the conclusion in their research report that although there had been an improvement in the past few years regarding education, housing and the employment conditions of individuals with higher qualifications, but the improvement was limited to individuals living in better conditions. Poverty and inequalities are closely connected. Ethnic poverty can be detected among the roma population; there is an accumulation of factors generating poverty in their case, the so-called "poverty risks", such as low levels of education, inactivity, unemployment, high number of children and regional disadvantages (Fónai 2008). Factors of structural disadvantages include, being pushed out of the labour market, as well as strong discrimination which became mutually intensifying processes (Babusik 2007). Data of many studies indicate that gender equality is yet to be achieved in Hungary. For the majority of men housework is still considered to be a "favor", as in helping with some household chores of women. Hungarian women work more than men: spending almost twice as much time on doing household chores, therefore they have much less time for leisure. 
Women without children have more chance of participating in the labour-market than those with children, but the situation is exactly the opposite in the case of men (Takács 2008). There is a new term in Hungarian society, being labour-market old, according to which an employee is considered to be elderly after 50, so here is a big age gap between what is "generally regarded as old", that has a lower limit of 70, and "labour-market old", which induces social problems beyond the discriminative behaviour of employers (Széman 2008).

The population of Hungary was 10 million 13 thousand on January 1st, 2010; 18 thousand less than a year earlier. Previously experienced changes continued in the composition of age groups. The number of children under 15 years of age decreased further, and did not reach one and a half million on January 1st, 2010. On the other hand, the number of people over the age of 65 increased, currently reaching close to 1.7 million. (17) The Northern Great Plain region is the second largest region in the country considering its population. It ranks in the top when it comes to both birth and mortality rates, with a better than national average ratio. The aging index is the lowest here (18), making the Northern Great Plain the region with the youngest age composition. (Figure 1.)

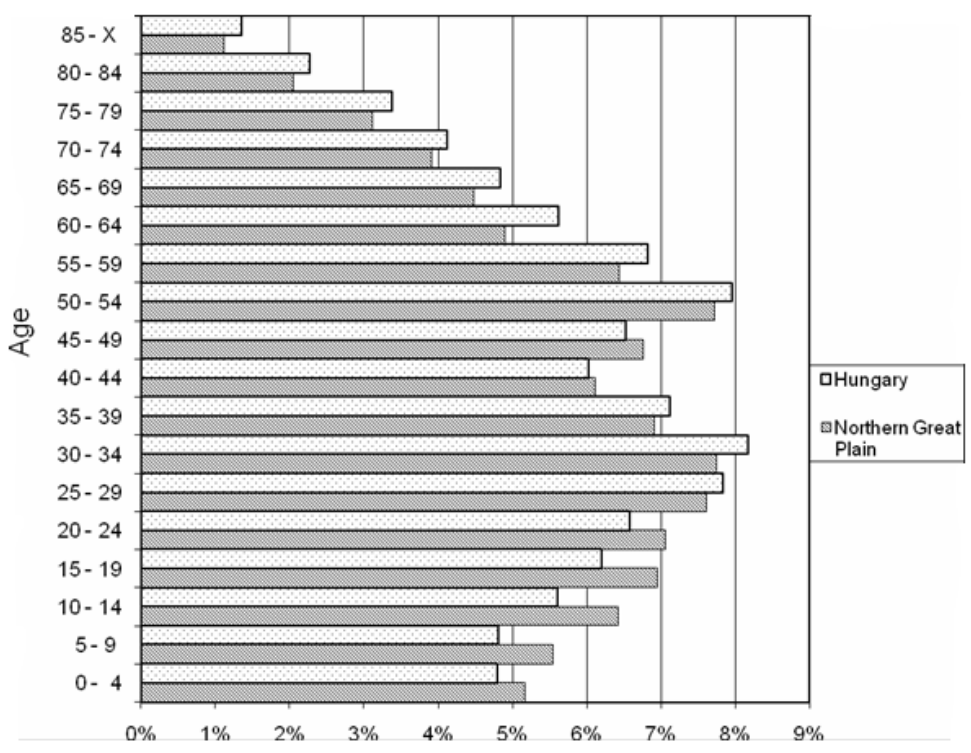

Figure 1: Age composition of Hungary and the Northern Great Plain region, 2009. Source: HCSO

The number of marriages was 36,750 in Hungary in 2009 and 23,800 marraiges 
were terminated. The ratio of divorced status was $10.7 \%$. In parallel, the ratio of individuals living in marriages was $45.8 \%$, which means that less than half the adult population is married. There were more than 471 thousand such single parent families in Hungary in 2001, where there was at least one supported child. The previously mentioned number included 58 thousand single fathers and 413 thousand single mothers. The traditional distribution of broken families persists, in fact the ratio of single mothers has increased from $79 \%$ to $88 \%$ since 1990 (Vukovich 1999). $29 \%$ of single mothers raise one younger than 15 year old child, $9 \%$ raise two children, while this ratio is $21 \%$ and $5 \%$ for single fathers respectively. $60 \%$ of single mothers and $72 \%$ of single fathers raise a child older than 15 . The number of single parents raising three or more children is much lower, making up $1 \%$ of single fathers and $2 \%$ of single mothers. $12 \%$ of single fathers and $11 \%$ of single mothers have tertiary degrees. $46 \%$ of fathers and $42 \%$ of mothers have secondary school education, while $47 \%$ of mothers and $42 \%$ of fathers have only received elementary school education. There is no significant difference between the distribution of single mothers and fathers according to qualification. The Northern Great Plain region has a high number of single parents when comparing the regions. (Figure2.)

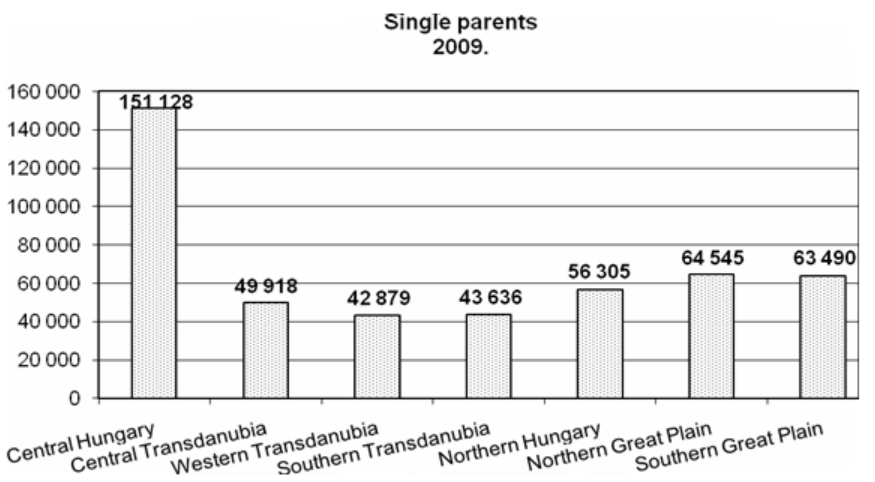

Figure 2: Number of single parents (capita) according to regions, 2009. Source: $\mathrm{HCSO}$

The high ratio of roma population has a significant effect on the demographic conditions of the region. The Northern Great Plain region ranked second behind the Northern-Hungarian region based on size of population who claimed to be roma (3.1\% within the population of the region) in 2001. (Figure 3.)

Although it is difficult to determine an accurate number due to several reasons, there could about 700,000 roma living in Hungary according to surveys and estimates, which makes up $7 \%$ of the total population. Estimating the age group and activity ratios, similarly to the total population, is also quite difficult and carries inaccuracies. The main reason for the low level of employment of roma is that at 


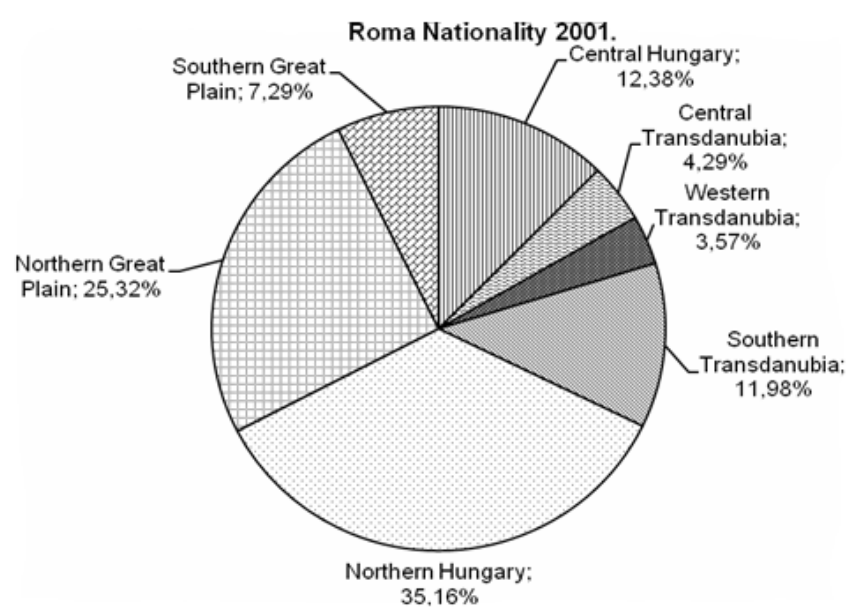

Figure 3: Distribution of roma among the regions of Hungary, 2001. Source: HCSO

most $80 \%$ of the active age group has completed elementary education. This ratio is close to $60 \%$ among the non-roma. About 400,000 of the 700,000 roma belong to the active age group. According to estimates, roughly $35 \%$ of the 700,000 roma, or 250 thousand are under the age of 15 , but only $7 \%$ or 50 thousand are over the age of 59, while 400 thousand can be regarded as belonging to the active age group (between 15-59). The activity rate of the 15-59 age group is only 40-50\%. Employment within the active age group is very low, while unemployment is significantly high at around $50 \%$. (19)

The economic crisis resulted in the increase of unemployment in Hungary, too. The unemployment rate was $10.1 \%$ in 2009 , compared to $7.9 \%$ a year before. All groups were affected by increasing unemployment in 2009. The situation is most unfavourable for the 15-24 year old age group, as unemployment among them increased from $19.9 \%$ to $26.5 \%$. (17) Considering the regional indicators, the highest ratio of employment among the 15-64 year-old age group $(61.6 \%)$ was still in the Central-Hungarian region along with the lowest unemployment rate $(6.7 \%)$. The lowest number of people from this age group actively working was in the Northern Great Plain region; their ratio was $48.1 \%$. (17)

The ratio of employment was very low within the 15-74 year-old age group in the Northern Great Plain region. Unemployment of the region shows a strong relationship with the employment conditions. The number of people economically inactive was 565,200 in the Northern Great Plain in 2009, which exceeds the national average in ratio. They made up $49 \%$ of the population between the age of $15-74$ in 
2009, while nationally made up a lower ratio of about $45 \%$. (Figure 4.)

\begin{tabular}{|c|c|c|c|c|c|c|}
\hline \multicolumn{7}{|c|}{$\begin{array}{l}\text { The 15-74 age group in the Northern Great Plain region according to economic activity } \\
\text { (thousand people) }\end{array}$} \\
\hline \multirow[t]{2}{*}{ Year } & \multicolumn{3}{|c|}{ Economically active } & \multicolumn{2}{|c|}{$\begin{array}{l}\text { Economically } \\
\text { inactive }\end{array}$} & \multirow[t]{2}{*}{ Total } \\
\hline & thousand people & Employed & Unemployed & $\begin{array}{l}\text { thousand } \\
\text { people }\end{array}$ & $\%$ & \\
\hline 2000 & 560.4 & 508.9 & 51.5 & 606.0 & $51.95 \%$ & 1166.4 \\
\hline 2001 & 559.6 & 516.1 & 43.5 & 607.3 & $52.04 \%$ & 1166.9 \\
\hline 2002 & 555.5 & 512.2 & 43.3 & 610.0 & $52.34 \%$ & 1165.5 \\
\hline 2003 & 572.7 & 534.0 & 38.7 & 590.0 & $50.74 \%$ & 1162.7 \\
\hline 2004 & 564.1 & 523.5 & 40.6 & 598.6 & $51.48 \%$ & 1162.7 \\
\hline 2005 & 569 & 517.4 & 51.6 & 589.5 & $50.88 \%$ & 1158.5 \\
\hline 2006 & 594.6 & 529.5 & 65.1 & 562.7 & $48.62 \%$ & 1157.3 \\
\hline 2007 & 584.9 & 521.7 & 63.2 & 566.3 & $49.19 \%$ & 1151.2 \\
\hline 2008 & 582.8 & 513.1 & 69.7 & 563.4 & $49.15 \%$ & 1146.2 \\
\hline 2009 & 570.2 & 489.1 & 81.1 & 565.2 & $49.78 \%$ & 1135.4 \\
\hline
\end{tabular}

Figure 4: The 15-74 year-old population in the Northern Great Plain region according to economic activity. Source: HCSO

The qualification of unemployed is more unfavourable in the region than at a national level. The majority of those looking for jobs have low qualifications, at the same time however, people with degrees represent an increasing number and ratio. (Figure 5.)

\begin{tabular}{|l|r|r|r|r|}
\hline \multicolumn{5}{|c|}{ Qualification of unemployed according to regions, 2009. } \\
\hline & $\begin{array}{r}8 \text { grades of elementary school } \\
\text { or lower }\end{array}$ & $\begin{array}{c}\text { Vocational } \\
\text { school }\end{array}$ & $\begin{array}{c}\text { Secondary } \\
\text { school }\end{array}$ & \multicolumn{1}{c|}{$\begin{array}{c}\text { College, } \\
\text { university }\end{array}$} \\
\hline Central Hungary & $23.40 \%$ & $28.08 \%$ & $31.85 \%$ & $16.55 \%$ \\
\hline $\begin{array}{l}\text { Central } \\
\text { Transdanubia }\end{array}$ & $35.36 \%$ & $38.06 \%$ & $20.27 \%$ & $6.31 \%$ \\
\hline $\begin{array}{l}\text { Western } \\
\text { Transdanubia }\end{array}$ & $32.12 \%$ & $32.38 \%$ & $28.50 \%$ & $6.74 \%$ \\
\hline $\begin{array}{l}\text { Southern } \\
\text { Transdanubia }\end{array}$ & $39.95 \%$ & $34.69 \%$ & $17.94 \%$ & $7.42 \%$ \\
\hline Northern Hungary & $33.94 \%$ & $35.07 \%$ & $26.20 \%$ & $4.79 \%$ \\
\hline $\begin{array}{l}\text { Northern Great } \\
\text { Plain }\end{array}$ & $35.02 \%$ & $32.80 \%$ & $24.04 \%$ & $8.26 \%$ \\
\hline $\begin{array}{l}\text { Southern Great } \\
\text { Plain }\end{array}$ & $27.22 \%$ & $39.50 \%$ & $25.44 \%$ & $7.83 \%$ \\
\hline Total & $31.64 \%$ & $33.82 \%$ & $25.62 \%$ & $8.91 \%$ \\
\hline
\end{tabular}

Figure 5: Levels of education according to regions, 2009. Source: HCSO

The age composition of the inactive population in the region is unique; the ratio of population in the 25-64 age group is the highest among the regions (51\%), which is connected to the relative high frequency of handicapped pensioners. (20) (Figure6.) 


\begin{tabular}{l} 
The number of economically non-active according to age groups (thousand people) \\
2009. \\
\hline
\end{tabular}

Figure 6: The number of economically inactive according to age groups in 2009 . Source: HCSO

The number of handicapped people was 577 thousand people in Hungary in 2001. Considering the data of the census, $5.7 \%$ of the population is handicapped. The employment ratio was $9 \%$ regarding economic activity in 2001 . The level of education of handicapped people is lower than those without any handicap. Altogether a quarter of those with a GCSE possess a tertiary degree. (18)

When examining the distribution of those living with a handicap according to regions, we can see that $15.97 \%$ of them live in the Northern Great Plain region. Their ratio within regions is indicated in the figure below. (Figure 7.)

\section{Ratio of those with a handicap}

2001.

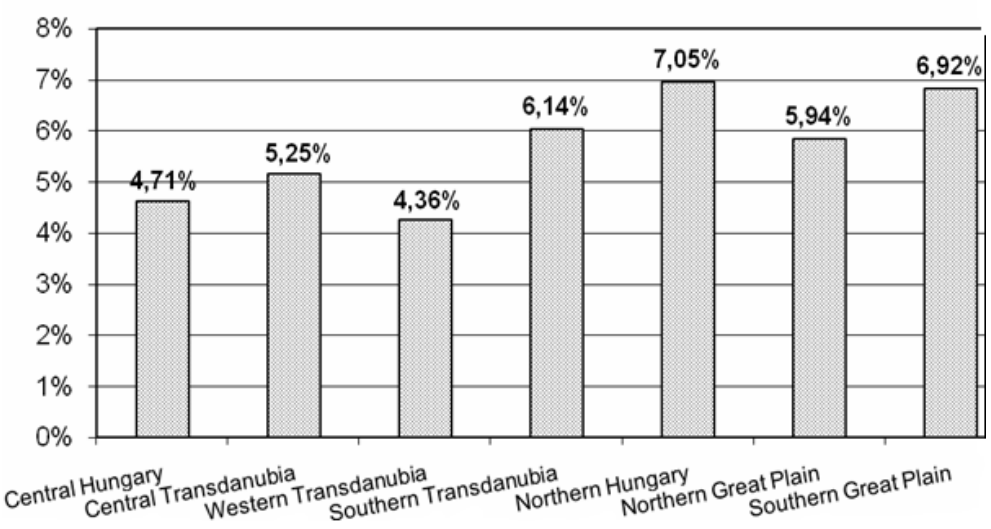

Figure 7: Ratio of those with a handicap in different regions of Hungary; 2001. Source: HCSO 


\section{Legislative environment}

The basic document that rules on ensuring equal opportunities in Hungary is the Constitution of Hungary. The Constitution rules: "ro/A. § (1) The Republic of Hungary ensures all human and citizens rights for all individuals residing in the country, without discrimination regarding their race, color, gender, language, religion, political or other views, national or social origin, wealth, birth or other conditions. (2) Any violation of paragraph (1) is subject to severe punishment by the law. (3) The Republic of Hungary assists the fulfilment of equal rights with actions aimed at eliminating inequalities. "1

Legislators took guidelines of EU legislative sources as a basis, naturally taking domestic peculiarities into account when creating the regulation above. Ensuring equal treatment has been present in the legislative documents of the Community since 1957. The Treaty on establishing the Europen Economic Community, which became known as the Treaty of Rome, is aimed at reducing inequalities between men and women with its renowned article $119 .^{2}$ The article I referred to attempts to solve the problem of unequal wages. This objective in the newly forming European economic and social framework, ten years following a world war, can be regarded as a great achievement, but the needs generated by social and economic parties today are more sophisticated which have to be addressed by legislators. Differing from the practices of previous years and decades, groups that had been almost completely neglected and ignored, including the roma, individuals with handicap or homosexuals, demanded and received a place. Due to increasing pressure, the legislative background maps out the environment, which provides the ground for initiatives aimed at strengthening equal treatment. Thus, if we examine Hungarian regulations in effect, concerning the application of equal opportunities, then we can see the multiplied aspects of achievements recorded in legislation.

The CXXV. Act of $2003^{3}$ is aimed at these issues in details. It does not only determine groups which interests are most often harmed or can be harmed, but it also clearly determines how somebody violates against equal opportunities, and outlines those organisations which are obliged to follow the requirements set by equal opportunities and also outlines certain additional obligations. We will examine these four aspects in details below.

The scope of the law extends to national, local and minority government organisations, including public and higher education institutions as well. ${ }^{4}$ The aim of this short-list is to make those rights and opportunities accessible for all members of

\footnotetext{
${ }^{1}$ A Magyar Köztársaság Alkotmánya 70/A. §

${ }^{2}$ Szerződés az Európai Gazdasági Közösség létrehozásáról 119. cikk

32003. évi CXXV. törvény az egyenlő bánásmódról és az esélyegyenlőség előmozdításáról.

${ }^{4}$ 2003. évi CXXV. törvény 4. §
} 
society, which are also included in the Constitution.

The law clearly articulates what can be regarded as discrimination and the criteria which forms the foundation for regarding someone as a member of a disadvantaged group. According to this "direct discriminatory regulation is one that puts a person or a group of people at a disadvantage based on their actual or presumed

a) gender,

b) race,

c) skin color,

d) nationality,

e) national or ethnic minority background,

f) mother tongue,

g) handicap,

h) health status,

i) religious or ideological beliefs,

j) political or other opinions,

k) marital status,

l) motherhood (pregnancy) or fatherhood,

m) sexual orientation,

n) sexual identity,

o) age,

p) social origin,

q) wealth,

r) part-time or limited length of employment or other labor status,

s) affiliation to interest groups,

t) other condition, characteristic or feature (from now on: characteristic), compared to other individuals or groups in a similar position. ${ }^{\prime 5}$

The abovementioned characteristics provide such general guidelines for affected organisations, which narrow down the most common problems, situations where guidelines for equal treatment could be violated. Naturally, the list, due to its general nature, can be interpreted in many ways. It is important therefore, that parties, obliged to follow the paragraphs of the law, must have thorough knowledge about the views of lawmakers in specific issues, as the complexity of the problems and nature of sensitive reactions that these may induce could urge parties to act with prudence in all circumstances.

\footnotetext{
${ }^{5}$ 2003. évi CXXV. törvény 8. §
} 


\section{The internal regulation of the University of Debrecen}

The examined institution, the University of Debrecen, must follow regulations on equal opportunities from many aspects. The organisation accepts over thirty thousand students and employs about six thousand employees, and being a state funded institution, the legal framework clearly outlines its obligations ${ }^{6}$ regarding these issues. The Equal Opportunity Act rules that financial organisations and legal entities with a majority state ownership employing more than fifty people are obliged to accept an equal opportunity plan based on the regulations ${ }^{7}$ of the Labour Law for a predetermined period, jointly with the trade union represented at the employer. The equal opportunity plan of the largest higher education institution of the Northern Great Plain came into effect on October 4th, 2007. As the document defines the university as an employer, it serves as a regulation of conditions between employer-employee. The plan includes the necessary legal references, which serves as basis for defining discrimination as well as the affected parties according to institutes. Considering that the University of Debrecen can also be regarded as a large scale enterprise, monitoring and controlling the implementation of equal opportunities can be regarded as an especially exciting challenge. The high number of employees and the wide and extensive organisational structure carries a number of potential pitfalls, as the affected parties are often unaware of their tasks and their rights regarding this issue. The institution prepared a survey in 2009, which revealed the extent to which the affected groups are present at the institution. The survey included the number of women, individuals with disabilities, families with young children and single parents. There are important data beside the listed indicators that are difficult to measure and examine. The abovementioned survey did not include many groups that are also affected in the current scope of issues. The primary reason for this lies in the contradiction of the regulations which on one hand encourages the tracking of data but on the other hand prohibits the conduction of such surveys; this unique phenomenon is decribed in the last part of my paper. In order to address this asymmetric situation, the institution took many specific measures, of few these are:

- Establishing an Equal Opportunities Committee.

- Gradual improvement of access to buildings for the disabled.

- Promoting equal access to training programs. ${ }^{8}$

Implementation of the abovementioned can be regarded as problem-free, as such developments and investments are continuous and the Equal Opportunties Com-

\footnotetext{
${ }^{6}$ 2003. évi CXXV. törvény 63. §(4)

${ }^{7}$ 1992. évi XXII. törvény a Munka Törvénykönyvérôl

${ }^{8}$ Debreceni Egyetem Esélyegyenlôségi Terve 8.§
} 
mittee fully fulfils the tasks its assigned to do:

"... prevention and handling of discriminative actions, development of activities ensuring equal opportunities, informing, counselling, promoting issues regarding equal opportunities."

As the university is obliged to meet requirements of equal opportunities with not only its employees but its students as well, the staff of the institution pays special attention to this as well. The educational institution made a separate regulation to ensure equal opportunities to students with disabilities, too. ${ }^{9}$ This document introduces the framework in details which aims to ensure equal opportunities to members of the affected groups. The regulation referred to above, had been developed based on the special needs of individuals with disabilities. The regulation divides those affected into many groups and protects their interests in different ways. This is totally understandable, as a blind student has to overcome different challenges than dysgraphic student. ${ }^{10}$ In order to achieve this, the university does not only address promoting the access to buildings for the disabled, but also support individuals with disabilities so that they do not experience any disadvantages compared to the majority of students. The importance of the issue is demonstrated by the fact that the Parliament passed a resolution and developed a program for the period 2007-2013 to improve the situation of those living with disabilities. ${ }^{11}$

\section{Equal opportunity requirements outlined in project calls}

The question might arise regarding the actual disadvantages if an institution does not follow the outlined path during its operation regardless of internal regulations and legal guidelines. There is a structure with a system of requirements which can track and if necessary could even investigate those institutions which do not comply with rules relating to equal opportunities. This framework is incorporated into the life of educational institutions through EU funded projects. The legal environment is given by the set of regulations connected to the European Regional Development Fund, the European Social Fund and Cohesion Fund. ${ }^{12}$ From our point of view, out of the two generally applied principles (equal opportunities and sustainable development), the aspects of equal opportunities are relevant. The abovementioned principle has had a significant role in shaping the New Hungary

\footnotetext{
${ }^{9}$ A Debreceni Egyetem szabályzata a fogyatékkal élő hallgatók esélyegyenlőségének biztosításáról.

${ }^{10}$ A Debreceni Egyetem szabályzata a fogyatékkal élő hallgatók esélyegyenlőségének biztosításáról 4 . §

${ }^{11} 10 / 2006$ (II. 16.) OGY Határozat az új fogyatékosügyi programról

$121083 / 2006 / \mathrm{EK}$ rendelet
} 
Development Plan (ÚMFT) ${ }^{13}$, as well in the development of specific operative programs. It also comes into effect in the decision making and executive process and has serious impact during the evaluation and selection of project applications. Those institutions that do not meet the requirements of equal treatment practically eliminate themselves from the funding system, which of course is a serious disadvantage in their operation. The importance of ensuring equal opportunities from a law making point of view is, I believe is best reflected in the text below: "All newly launched, state and EU funded investments must meet the requirements of easy access to the planned building or construction, public transport or other publicly used establishment... Infocommunicative access must also be ensured for eliminating the digital illiteracy of disabled people which provides access to public services through the application of infocommunicative tools and solutions. Personal and material requirements must be provided in order to achieve this goal." 14

Public institutions must meet more specific obligations than the regulations referred to above, when applying for European Union funds. This is primarily due to the fact that non-refundable funds must be spent on the development of specific areas, therefore the am is to fully comply with requirements of equal opportunities and meet the expectations of specific target groups. These priorities are always determined by the nature of the funded area.

There are such regularly reoccurring problems regarding equal opportunities which are addressed by specific project funds. These are so outstanding that foreign researchers also deal with them in their country reports (Watson, 2002). It is natural that in a call which is aimed at promoting the reintegration of women into the labour market, a disabled man cannot be regarded as member of the target group, so it cannot be regarded as discrimination either. There are such funding constructions that pay attention to ensuring the equal opportunies to several groups. A perfect example is the call entitled "Support for infrastructural development in health centers" wihin the Social Infrastructure Operative Program. ${ }^{15}$ Although the developments allowing construction and purchase of medical equipment result in direct utilization at the specific institution, their indirect affects can be detected at regional and interregional levels as well. Those making the call, similarly to other project calls, require the applicants to meet strict conditions.

The equal opportunity guideline of this call determines the following target groups and problems:

- Establishing and strengthening a family friendly workplace.

- Reducing differences in opportunities between genders (men and women).

- Promoting easy access to locations.

\footnotetext{
${ }^{13}$ Új Magyarország Fejlesztési Terv 2007-2013

1410/2006. (II. 16.) OGY htározat Az új országos Fogyatékosügyi Programról 31-32. oldal

${ }^{15}$ Társadalmi Infrastruktúra Operatív Program - 2.2.7/07/2F
} 
- Improving the quality of life and labour market opportunities for people with disabilities.

- Improving the quality of life and labour market opportunities of the roma.

- Improving labour market opportunities and social opportunities of other disadvantaged groups.

Based on a list of criteria outlined in the points, the applicant - the University of Debrecen - has to provide proofs through previous, already implemented and planned actions, which due to their exact nature leave no room for misinterpretation and represent a verifiable responsibility for the organisation. The form must indicate, among others, the number of buildings that are easily accessible and the number of roma and disabled employees.

Completing the abovementioned complex tasks is a serious challenge for the educational institution, which is a result of previously mentioned contradicting legal environment. It is a serious problem when the public institution has to collect data that representatives of specific groups are not willing to share, such as religious beliefs, ethnic identity etc., and the law regarding data protection does not allow to do so. ${ }^{16}$ The law in effect states that data are considered as special if they are in connection with:

"a) racial origin, nationality and ethnic minority, political opinion, religious or other beliefs, membership in interest groups,

b) health condition, addiction, sexual habits or personal criminal records. "17

The law has especially strict regulations for handling such information:

"Special data can be handled, if

a) the affected person gives written permission, or as it is included in points

b) a 2. §2. a) is based on an international agreement, or the law orders to do so in the interest of enforcing basic rights ensured in the Constitution, or in the interest of national security, crime prevention and crime tracking;

c) the law orders in other cases. "18

\section{Data of the survey by the University of Debrecen}

Gender or age discrimination must be investigated first from the discrimination cases at the workplace (Konz, 1999). The table below shows relevant data of the University of Debrecen, which illustrates that neither age nor gender discrimantion is present among the employees. (Figure 8.)

\footnotetext{
161992. évi LXIII. törvény a személyes adatok védelmérôl és a közérdekú adatok nyilvánosságáról

${ }^{17}$ 1992. évi LXII törvény 2 . §. (2) a-b

18 1992. évi LXII törvény 3. §. (2) a-b
} 


\begin{tabular}{|l|c|c|}
\hline Data of the University of Debrecen & $\begin{array}{c}\text { Number } \\
\text { (person) }\end{array}$ & $\begin{array}{c}\% \\
\text { ratio }\end{array}$ \\
\hline General statistical staff number & 5987 & - \\
\hline Number of female employees & 3946 & $66 \%$ \\
\hline $\begin{array}{l}\text { Number of employees older than 50 years old, with an indefinite } \\
\text { length contract }\end{array}$ & 1316 & $22 \%$ \\
\hline Number of employees working in the top and middle management & 348 & - \\
\hline Number of female employes in top and middle management & 139 & $40 \%$ \\
\hline
\end{tabular}

Figure 8: Data of the University of Debrecen, 2010. Source: www.unideb.hu

The University of Debrecen carried out a survey in 2009, in which volunteers from the employees of the institution were interviewed anonymously about their ethnic backgrounds, or disabilities etc. 3180 people filled in the questionnaire out of the 5831 employees. $11.6 \%$ of those who filled in the questionnaire are single parents. $0.9 \%$ of respondents claimed to be roma and $1.9 \%$ claimed any disability.

If we consider that the majority of employees at the University of Debrecen have a higher education degree, and about $2 \%$ have a GCSE, then we can see that the number of roma employees is limited due to their lack of qualification. We can find similar reasons behind the number of employees with disabilities.

This survey, due to its volunteer basis, does not give an accurate picture. However, because of the previously described legal peculiarities, it is not possible to measure indicators needed for funding applications. This means that the organisation is under dual pressure as on the one hand there is a demand for data and on the other hand there is limited data that makes it difficult to meet such requirements.

\section{Summary}

We can say that any action aimed ensuring equal opportunities can only reach its objective if it is in place and is implemented on an everday basis and it is not only present on paper or in statistics but is practically in effect. It is typical of Hungarian empiric research that due to related legal regulations, data regarding population are deficient. We can take the data of the 2001 census into account, where terms and categories require clarification (Fónai 2007). We can find significantly differing data sequences about the educational background of the roma population which can cause classification problems (Fónai 2008).

Reasons are one of the basic problems of social developments as they are often questionable, since sufficient amount and quality of data are not provided for determining directions for development. On the other hand, massive amount of data flows to organisations responsible for developments, because the applicants have to provide a wide range of information about their activities, execution of their 
programs and results, but the processing does not happen for many years following the completion of the programs and thus they are not published (Bugarszki and assoc. 2010).

At the same time, the fate of people and families with disabilities and in disadvantaged situations is alarming, as they have to tackle unemployment and other social disadvantages on a daily basis.

An important condition of implementing equal opportunity requirements in practice is to set up and expand personal and infrastructural conditions needed for achieving this goal. It is essential that government and civil organisations pay attention to the dissemination of equal opportunity approaches. The role of education in shaping social approach is crucial (Koncz 2006).

Based on regional demographic data, we must focus on disadvantaged people to ensure equal rights to them. The University of Debrecen, as one of the large employers of the region, meets legal regulations regarding equal opportunities and pays special attention to various aspects of equal opportunities during its funded development activities. However, as the ex-ante evaluation of TÁRKI (Tóth, 2007) also called the attention to it, only a few of the UMFT (New Hungary Development Plan) operative programs take the multi-dimensional aspect of disadvantaged situation into consideration. Therefore, the projects with single dimensions, aimed at achieving one certain goal (e.g. training, creation of jobs), are not suitable for really supporting those who live in the most difficult situations. Only a focused, complex support program can provide a real solution for them. (Pulay, 2008)

\section{Bibliography}

1. Babusik, Ferenc (2007): Magyarországi cigányság - stuktúrális csapda és kirekesztés. Esély 1. (Hungarian roma - structural traps and isolation)

2. Bass, L.-Darvas, Á.- Ferge, Zs.-Simon, M. (2008): A gyermekszegénység csökkentése továbbra is kulcskérdés. A Gyermekszegénység elleni Nemzeti Program első két évéról. Esély 4. 25-52. (Reducing child poverty is still a key issue. - On the first two years of the National Program against child poverty).

3. Bugarszki, Zsolt and assoc. (2010): „Egy lépés eloore, kettő hátra” A nagy létszámú intézmények kitagolása és az önálló életvitel támogatása Magyarországon, az Európai Unió strukturális alapjainak felhasználásával; ELTE Társadalomtudományi Kar, Sotéria Alapítvány, Budapest, 2010. "A step forward, two steps back".

4. Ferge, Zsuzsa (2008): Miért szokatlanul nagyok a magyarországi egyenlőtlenségek? Esély 2. (Why are inequalities so unusually great in Hungary?)

5. Fónai, Mihály - Pásztor, Enikô - Zolnai, Erika (2007) A fogyatékos emberek helyzete, életmódja és életkörülményei Hajdú-Bihar megyében. Esély 6. 87-119. (The situation of disabled people, their lifestyle and living conditions in HajdúBihar county)

6. Fónai, Mihály (2008): A romák társadalmi helyzete és egészségi állapota É- 
szakkelet-Magyarorszáq-gon; Habilitációs értekezés (Social and health condition of roma in Northeast-Hungary)

7. Koncz, Katalin (1999): Esélyegyenlőség az Európai Unió prioritásai között. Munkaügyi Szemle, Vol. XLIII. 1999. 5. sz. 19-24. 1. (Equal opportunties among the priorities of the European Union)

8. Koncz, Katalin (2006): Diszkrimináció a munkahelyen 1. rész 50. évf. 2006/1.sz. 11-14.

9. Pulay, Gyula - Benkô, János (2008): A magyarországi cigányság helyzetének javítására és felemelkedésére a rendszerváltás óta fordított támogatások mértéke és hatékonysága; Összegzô, helyzetfeltáró tanulmány (Szerk: Báger Gusztáv); Állami Számvevőszék Fejlesztési és Módszertani Intézet, 2008. április; 65. (The extent and effectiveness of funds spent on improving the situation of roma in Hungary since the change of regime)

10. Spéder, Zsolt (1996): Ikertestvérek - A szegénység arcai a mai Magyarországon. Századvég. 2: 29-59. (Twins - The current face of poverty in Hungary today)

11. Spéder, Zsolt (2002): A szegénység változó arcai: tények és értelmezések. Budapest: Andorka Rudolf Társadalomtudományi Társaság - Századvég. (Changing faces of poverty: facts and interpretations.)

12. Széman, Zsuzsa (2008): Ki az idôs? Az öregedés különbözô szempontjai. Esély 3. 3-15. (Who is elderly? Different aspects of ageing.)

13. Takács, Judit (2008): „Ha a mosogatógép nem lenne, már elváltunk volna ... " Férfiak és nók otthoni munkamegosztása európai összehasonlításban. Esély 6 . "If there had not been a washing machine, we would have divorced by now ..." Sharing household chores between men and women in a European comparison.

14. Tóth István, György and assoc. (2007): Az Új Magyarország Fejlesztési Terv Operatív Programjainak horizontális ex-ante értékelése. TÁRKI Zrt. 2007. (Horizontal ex-ante evaluation of the New Hungary Development Operative Programs) 15. Vukovich, Gabriella (1999): „Egyedülálló szülook és gyermeküket egyedül nevelő szülők" in: Szerepváltozások. Jelentés a nôk és férfiak helyzetérôl, 1999, Pongrácz Tiborné, Tóth István György, (szerk.). Budapest: TÁRKI, Szociális és Családügyi Minisztérium, 63-73. "Single parents and parents raising their children alone" in: Changing roles. Report on the situation of women and men

16. Watson, N. - Linderberg, U. - Vörös, M. (2002): Monitoring the EU Accession Process: Equal Opportunities for Women and Men, Open Society Institute EU Accession Monitoring program. Budapest, 2002.

17. http://portal.ksh.hu/pls/ksh/docs/hun/xftp/idoszaki/mo/mo2009.pdf;

Magyarország 2009: Központi Statisztikai Hivatal (HCSO), Budapest, 2010.

18. Lakatos, Judit - Tokaji, Károlyné (2009): Társadalmi jellemzôk és ellátórendszerek (Social characteristics and support systems), 2008.: Központi Statisztikai Hivatal (HCSO), Budapest, 2009; 53-63.

19. http://www.cemi.hu/

Central European Management Intelligence (CEMI) (2006): Makro egyensúly és gazdasági növekedés, tanulmány (Study on macro balance and economic growth), 
2006, 130-138.; (2010. 12. 20.)

20. http://portal.ksh.hu/

Statisztikai Tükör II. 135. Munkaerô-piaci folyamatok az Észak-Alföldön (Labourmarket processes in the Northern Great Plain), 2000-2007; KSH (HCSO); 2008. október 14. (2010.11.08.)

\section{Ildikó Balatoni:}

University of Debrecen, Health and Science Center, leader of the Office of Strategic Management 